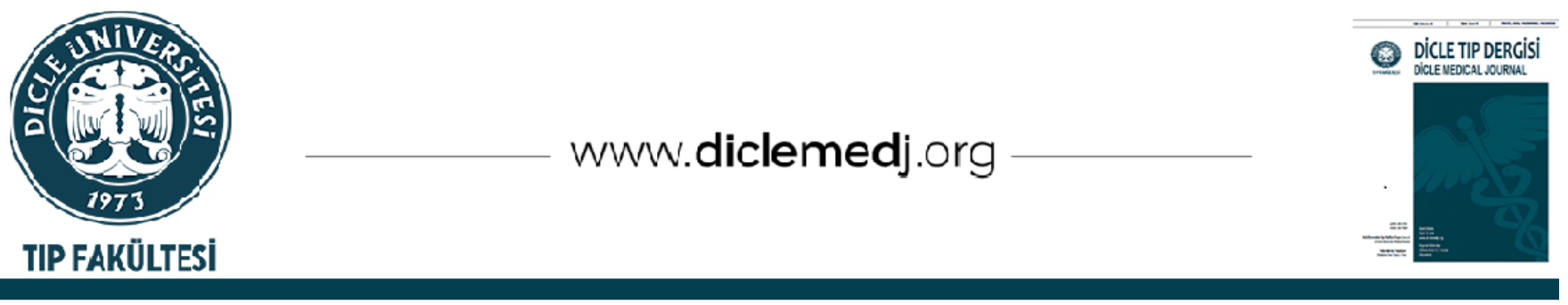

Original Article / Özgün Araştırma

\title{
The Monocyte To High-Density Lipoprotein Cholesterol Ratio Predicts The Mortality in Patients With Reduced Ejection Fraction Heart Failure
}

\author{
Seçkin Dereli ${ }^{\text {1 }}$, Nurtaç Özer iD 2, Yasemin Kaya ${ }^{\text {iD }}$, Ahmet Kaya ${ }^{D}$ 1, Osman Bektaş ${ }^{\text {1D }}$, \\ Mustafa Yenerçăg iD 1 , Mehmet Filiz iD 1 , Fatih Akkaya i 1 \\ 1 Ordu University, Faculty of Medicine, Department of cardiology, Ordu, Turkey \\ 2 Ordu State Hospital, Department of cardiology, Ordu, Turkey \\ 3 Ordu University, Faculty of Medicine, Department of Internal Medicine, Ordu, Turkey
}

Received: 24.11.2020; Revised: 15.12.2020; Accepted: 16.12.2020

\begin{abstract}
Objective: We purposed to evaluate the association between Monocyte To High-Density Lipoprotein Cholesterol Ratio (MHR) and mortality during a year follow-up in patients with reduced efection fraction heart failure (HFrEF).

Method: We included total of 552 patients with HFrEF into the study. The main outcome was mortality at 1-year followup. Sociodemographic characteristics, hemogram and biochemical parameters, ejection fractions of patients were recorded. MHR was was computed by splitting monocyte into high-density lipoprotein cholesterol (HDL-C).

Results: The HFrEF population were seperated into different groups as non-survivors ( $n=45$ ) and survivors ( $n=507)$. When the groups are compared the non-survivors group was older $(\mathrm{p}=0.04)$ and chronic renal failure incidence was higher in non-survivors $(\mathrm{p}=0.001)$. The MHR was notably higher in the non-survivors group $(\mathrm{p}=0.000)$. We have shown that MHR had a positive correlation with mortality $(\mathrm{r}=0.146 \mathrm{p}=0.001)$. Also higher MHR was found as a strong paramer to predict of mortality (Odds ratio: $2.471,95 \%$ confidence interval: $1.729-4.092, \mathrm{P}=0.005$ ). The cut-off values of 6,39 might be applied for predicting the mortality with $88 \%$ sensitivity and 97\% specificity [Area under curve:0.831 (95\% Confidence Interval: 0.799-0.869) $\mathrm{p}=0.001]$.
\end{abstract}

Conclusion: MHR can be used as an easy and usefull tool to predict mortality in HFrEF patients.

Keywords: heart failure, mortality, monocyte to high-density lipoprotein cholesterol ratio

DOI: 10.5798/dicletip.850294

Correspondence / Yazışma Adresi: Seçkin Dereli, Ordu University Faculty of Medicine Department of Cardiology, 52000, Ordu, Turkey e-mail:drseckindereli@gmail.com 


\section{Monositin Yüksek Dansiteli Lipoprotein Kolesterole Oranı Düşük Ejeksiyon Fraksiyonlu Kalp Yetmezliği Hastalarında Mortaliteyi Öngördürür}

Öz

Amaç: Düşük ejeksiyon fraksionlu kalp yetmezliği (DEFKY) hastalarında Monosit ile Yüksek Dansiteli Lipoprotein Kolesterol Oranı (MHR) ve 1 yıllık takipteki ölüm oranı arasındaki ilişkiyi araştırmayı amaçladık.

Yöntemler: Çalışmaya 552 DEFKY hastası dahil edildi. Ana değerlendirme sonucu 1 yıllık takipteki ölümdü. Hastaların sosyodemografik özellikleri, hemogram ve biyokimyasal parametreleri, ejeksiyon fraksiyonları kaydedildi. MHR, monositin yüksek dansiteli lipoprotein kolesterolüne (HDL-C) bölünmesiyle hesaplandı.

Bulgular: Hastalar ölenler ( $n=45)$ ve să̆ kalanlar $(n=507)$ olarak iki gruba ayrıldı. Gruplar karşılaştırıldığında ölenler grubu daha yaşlıydı $(p=0,04)$ ve kronik böbrek yetmezliği sıklığı ölenlerde daha yüksekti $(p=0,001)$. MHR ölenler grubunda belirgin derecede yüksek idi $(\mathrm{p}=0.001)$. MHR ile ölüm arasında pozitif bir korelasyon vardı $(\mathrm{r}=0.146 \mathrm{p}=$ 0.001). Ayrıca yüksek MHR, ölümü öngördüren bağımsız bir faktör olarak bulundu (Odds oranı: $2.471,95 \%$ güven aralı̆̆ı: 1.729-4.092, p=0.005). MHR, 6,39 sınır değeri ile \%88 duyarlılık ve \%97 özgüllük ile ölümü tahmin etmek için kullanılabileceği gösterildi. [Eğri altındaki alan: 0,831 (\%95 güven aralığı: 0,799-0,869) p = 0,001].

Sonuç: MHR, kalp yetmezliği olan hastalarda ölümü öngördürmede bağımsız bir parametre olabilir.

Anahtar kelimeler: Kalp yetmezliği, Ölüm, Monosit/Yüksek Dansiteli Lipoprotein Kolesterol Oranı.

\section{INTRODUCTION}

Heart failure (HF) as a chronic cardiovascular disease is prevalent in the elderly people and has a higher mortality rate despite modern and current treatments ${ }^{1,2}$. Studies have shown that inflammation is related with reduced left ventricular ejection fraction (LVEF) and poor cardiovascular prognosis in patients with reduced ejection fraction (HFrEF) ${ }^{3}$. Recently, with the prominence of interest in inflammatory biomarkers, it has been evaluated that there is a strong associaton between prognosis and those markers in $\mathrm{HFrEF}^{4,5}$.

Monocytes cells are produced in the bone marrow and take significant part in the immune system that turn into macrophages and dendritic cells in tissues. These cells also have the capacity to secrete both proinflammatory and prooxidant cytokines ${ }^{6,7}$. High-density lipoprotein cholesterol (HDL-C) carries cholesterol from peripheral tissues to the liver, and has also been confirmed to be involved in anti-inflammatory, antioxidant and antithrombotic processes ${ }^{8,9}$. The relationship of monocyte to HDL-C ratio (MHR) with the progression and presence of cardiovascular disease has been demonstrated by many different studies ${ }^{10,11}$.

In this study, we aimed to show whether MHR is associated with mortality in patients with HFrEF.

\section{METHOD}

Between June 2015 and April 2020, A total of 552 HFrEF patients who followed up at the cardiology outpatient clinic included in to our study. The inclusion criteria of the study were the presence of LVEF below $40 \%$ and having a New York Heart Association (NYHA) functional class $\geq$ II. The exclusion criteria were as follows: (i) any implantable defibriator device (CRTD\&ICD) implantation in the 6-month period prior to inclusion and at the 1-year follow-up period after inclusion, (ii) presence of malignancy, infection, chronic inflammatory disease and (iii) history of an acute coronary syndrome, surgery, or trauma history at the one year follow-up. MHR was computed by splitting monocyte into HDL-C. Neutrophil to lymphocyte ratio (NLR) was computed by splitting neutrophils and lymphocytes and platelet to lymphocyte ratio (PLR) was 
computed by splitting platelet into lymphocytes.

Age, gender, chronic diseases, hemogram and biochemical data, LVEF of patients were recorded at the admission of outpatient clinic. The main outcome was mortality at 1-year follow-up. Information concerning cases of mortality was acquired from the hospital software, telephone meeting, and the health system database.

\section{Statistical Analysis}

SPSS 22.0 Statistical Program (SPSS Inc., Chicago, IL, USA) was applied. The dispersion of data was estimated with Kolmogorov-Smirnov test. Mann Whitney U test was performed to estimate of not ordinarily dispersing data between groups. Student$T$ test was performed for ordinarily dispersing data. In order to test the difference of the categorical parameters between the groups, Chi-square test was used. The numeric parameters as median (minimum and maximum) and mean $\pm \mathrm{SD}$, the categorical parameters as percentage were expressed. A Spearman correlation analyse was employed to examine the relationship of the MHR and the different clinical and laboratuary parameters. Receiver operating characteristics (ROC) curves analyses were completed to acquire the area under the curves (AUC) of the inflammatory biomarkers to predict mortality in HFrEF. The predictive validities were measured as the AUC by c statistics, and these crosschecks were applied by MedCalc statistical software (Delong's test). Cox regression multivariable analysis was performed for long-term survival including variables with p-values less than 0.05 in univariate analysis. P-values, Odds ratio (OR) with 95\% CI were calculated. Traditional risk factors such as age, gender, LVEF, NYHA class, DM, HT and laboratuary markers were included in these variables. $\mathrm{P}<0.05$ was considered statistically significant.

The study was confirmed by the Ordu University Clinical Research Ethics Committee (12/03/202006-45). Inscriptive aware consent was acquired obtained from all patients.

\section{RESULTS}

Of the 552 patients with $\mathrm{HFrEF}, 45$ died at the one year follow-up (mortality rate $=8.1 \%$ ). The average pursuit time interval was $15.2 \pm 3.5$ months. The study population was classified according to survival status as survivors and non-survivor. In patients with HFrEF; when survivors and nonsurvivor groups were compared in terms of sociodemographic features, the non-survivors group was older (survivors group 65.26 \pm 11.23 nonsurvivors group $70.47 \pm 12.21, \mathrm{p}=0.04$ ) and CKD was higher in the non-survivors group (survivors group $12 \%$ non-survivors group $\% 30, p=0.001$ ) There was no significant difference between the groups according to gender, DM, HT, HL, smoking (Table 1).

Table I: Basic Characteristics of The Study Groups

\begin{tabular}{|c|c|c|c|}
\hline & $\begin{array}{l}\text { Survivors } \\
\text { N: } \mathbf{5 0 7}\end{array}$ & $\begin{array}{c}\text { Non- } \\
\text { survivors } \\
\text { N:45 }\end{array}$ & P value \\
\hline Age (year) & $65.26 \pm 11.23$ & $70.47 \pm 12.21$ & 0.04 \\
\hline Gender (male, n \%) & $319(62 \%)$ & $33(72 \%)$ & 0.280 \\
\hline Ischemic etiology (n, \%) & $314(62 \%)$ & $27(60 \%)$ & 0.274 \\
\hline Diabetes mellitus (n, \%) & $157(30 \%)$ & $13(30 \%)$ & 0.730 \\
\hline Hypertension (n, \%) & $261(51 \%)$ & $20(43 \%)$ & 0.610 \\
\hline $\begin{array}{lll}\text { Chronic } & \text { kidney } & \text { disease } \\
(\mathrm{n}, \%) & & \\
\end{array}$ & $60(12 \%)$ & $14(30 \%)$ & 0.001 \\
\hline Hyperlipidemia (n,\%) & $87(17 \%)$ & $6(13 \%)$ & 0.540 \\
\hline Smoking (n, \%) & $109(21 \%)$ & $9(19 \%)$ & 0.840 \\
\hline NYHA class III-IV (n, \%) & $183(36 \%)$ & $23(51 \%)$ & 0.001 \\
\hline \multicolumn{4}{|c|}{ Guideline directed heart failure therapy } \\
\hline ACEI \& ARB (n, \%) & $228(45 \%)$ & $19(42 \%)$ & 0.372 \\
\hline Sacubtril/valsartan (n, \%) & 107 (21\%) & $7(15 \%)$ & 0.009 \\
\hline Beta-blocker (n,\%) & $426(88 \%)$ & $39(87 \%)$ & 0.765 \\
\hline $\begin{array}{l}\text { Aldosterone antagonist (n, } \\
\%)\end{array}$ & $370(73 \%)$ & $32(71 \%)$ & 0.260 \\
\hline Loop diuretic $(n, \%)$ & $309(61 \%)$ & $36(80 \%)$ & 0.003 \\
\hline Ivabradine $(\mathrm{n}, \%)$ & 107 (21\%) & $11(24 \%)$ & 0.439 \\
\hline Statin (n,\%) & $101(20 \%)$ & $10(22 \%)$ & 0.618 \\
\hline ICD\&CRT-D (n,\%) & $102(21 \%)$ & $11(24 \%)$ & 0.509 \\
\hline
\end{tabular}

Categorical parameters were demonstrated as numbers and percentage, numerical parameters were demonstrated as mean $\pm S D$ or median (minmax)NHYA: New York Heart Association; ACEI: angiotensin-converting enzyme inhibitor; ARB: angiotensin receptor blocker; ICD: Implantable cardiac defibrilator; CRT: cardiac resynchronization therapy 
When groups were checked against according to biochemical parameters; urea, creatinine, aspartate aminotransferase (AST), white blood cell (WBC), monocytes, troponin, pro-B-type natriuretic peptide (proBNP) were higher in the non-survivors group (respectively $\mathrm{p}=0.003, \mathrm{p}=0.002, \mathrm{p}=0.001 \mathrm{p}=$ 0.038, $\mathrm{p}=0.003, \mathrm{p}=0.053, \mathrm{p}=0.014$ ). TC, TG, HDL-C and LVEF were lower in the non-survivors group (respectively $\mathrm{p}=0.052 \mathrm{p}=0.007 \mathrm{p}=0.023 \mathrm{p}=0.001$ ) (Table 2). We found the MHR and other inflamatuary biomarkers NLR, PLR were significantly higher in the non-survivors group ( $\mathrm{p}=0.001$ for all) (Table 2 ) (Figure 1).

Table II: Comparison of Blood Parameters And Ejection Fractions of Study Groups

\begin{tabular}{|c|c|c|c|}
\hline Variables & $\begin{array}{c}\text { Survivors } \\
\text { N: } \mathbf{5 0 7}\end{array}$ & $\begin{array}{c}\text { Non-survivors } \\
\text { N:45 }\end{array}$ & $P$ value \\
\hline Glucose (mg/dl) & $100(64-536)$ & $202.5(72-425)$ & 0.123 \\
\hline Urea (mg/dl) & $37(6-236)$ & $44(16-208)$ & 0.003 \\
\hline Creatinine (mg/dl) & $0.91(0.4-11.2)$ & $1.2(0.6-6)$ & 0.002 \\
\hline AST (U/L) & $22(3-414)$ & $26(12-756)$ & 0.001 \\
\hline ALT (U/L) & $19(5-453)$ & $19.50(5-146)$ & 0.115 \\
\hline Total cholesterol (mg/dl) & $178(42-407)$ & $172(106-287)$ & 0.052 \\
\hline Triglycerides (mg/dl) & $128.5(17-1181)$ & $108.50(59-294)$ & 0.007 \\
\hline LDL-C (mg/dl) & $114(11-2584)$ & $114.10(11-164)$ & 0.884 \\
\hline HDL-C (mg/dl) & $39(16-74)$ & $32(23-79)$ & 0.023 \\
\hline $\mathrm{CRP}(\mathrm{mg} / \mathrm{L})$ & $5.1(0.06-73)$ & $5.1(0.6-72)$ & 0.949 \\
\hline Hemoglobin $(\mathrm{g} / \mathrm{dl})$ & $14(8.38-19.10)$ & $13.05(7.4-18)$ & 0.124 \\
\hline $\mathrm{WBC}\left(\mathrm{X} 10^{6} \mathrm{U} / \mathrm{L}\right)$ & $7.700(1.900-30.900)$ & $8.100(4.100-46.400)$ & 0.038 \\
\hline Platelets $\left(\mathrm{x} 10^{6} \mu \mathrm{l}\right)$ & $218.000(10.400-781.000)$ & $202500(72000-425000)$ & 0.197 \\
\hline Lymphocytes $\left(\mathrm{x} 10{ }^{6} \mu \mathrm{l}\right)$ & $1.500(0.00-9.220)$ & $1.400(400-2.600)$ & 0.109 \\
\hline Monocytes $\left(\mathrm{x} 10^{6} \mu \mathrm{l}\right)$ & $600(0.00-2800)$ & $700(300-2800)$ & 0.003 \\
\hline Troponin $(\mu \mathrm{g} / \mathrm{L})$ & $0.012(0.001-38.7)$ & $0.053(0.014-42.0)$ & 0.053 \\
\hline proBNP $(\mathrm{pg} / \mathrm{ml})$ & $2441(32.26-25800)$ & $3321(48-21400)$ & 0.014 \\
\hline MHR & $13.95(0.00-83.87)$ & $20.68(6.33-40.58)$ & 0.001 \\
\hline NLR & $2.3(1.5-2.7)$ & $3.6(3.1-4.9)$ & 0.001 \\
\hline PLR & $114(87-144)$ & $147(128-201)$ & 0.001 \\
\hline LVEF (\%) & $30(15-45)$ & $25(15-40)$ & 0.001 \\
\hline
\end{tabular}

Categorical variables were demonsrated as numbers and percentage, numerical variables were demonsrated as mean \pm SD or median (min-max)AST: aspartate aminotransferase; ALT: alanine aminotransferase; HDL-C: High density lipoprotein cholesterol; LDL-C: Low-density lipoprotein cholesterol; CRP:C-reactive protein; WBC: White blood cell; BNP: pro-B-type natriuretic peptide; MHR: Monocyte to high-density lipoprotein cholesterol ratio; NLR: Neutrophil to lymphocyte ratio; PLR: platelet to lymphocyte ratio; LVEF: Left ventricular ejection fraction; 


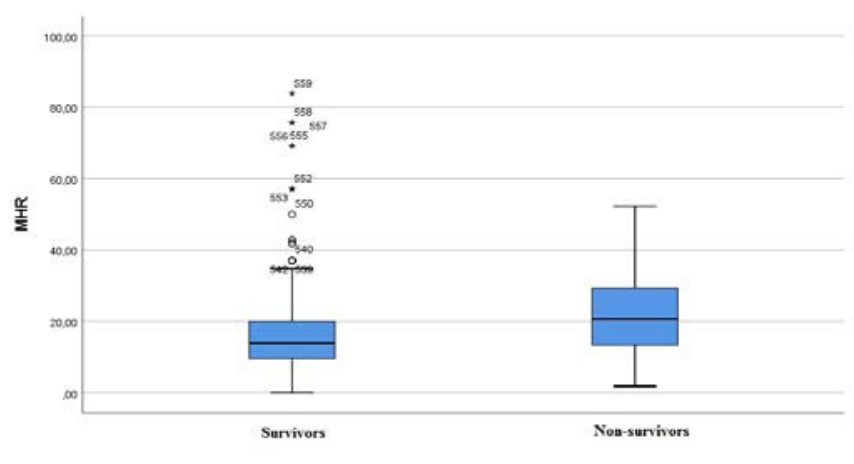

Figure 1. Comparison of Monocyte to high-density lipoprotein cholesterol ratio (MHR) between two groups

Table III: Correlation Between MHR and Clinical Characteristics of Population

\begin{tabular}{|l|c|c|}
\hline & $r$ & $P$ \\
\hline Age & 0.156 & $<0.001$ \\
\hline Male & 0.185 & $<0.001$ \\
\hline Smoking & 0.055 & 0.043 \\
\hline Diabetes mellitus & 0.084 & 0.002 \\
\hline Chronic kidney disease & 0.190 & $<0.001$ \\
\hline proBNP & 0.274 & $<0.001$ \\
\hline Albumin & -0.202 & $<0.001$ \\
\hline Creatinine & 0.193 & $<0.001$ \\
\hline Cholesterol & -0.090 & 0.001 \\
\hline C-reactive protein & 0.108 & 0.004 \\
\hline White blood cell & 0.312 & $<0.001$ \\
\hline Left ventricular & -0.142 & $<0.001$ \\
\hline fraction & 0.146 & $<0.001$ \\
\hline Sacubitril/valsartan & -0.071 & $<0.001$ \\
\hline NLR & & 0.002 \\
\hline PLR & & \\
\hline Statins & & \\
\hline & & \\
\hline NYHA class & & \\
\hline & & \\
\hline
\end{tabular}

MHR: Monocyte to high-density lipoprotein cholesterol ratio; BNP: proB-type natriuretic peptide; NLR: Neutrophil to lymphocyte ratio; PLR: platelet to lymphocyte ratio; NHYA: New York Heart Association;

The results of the correlation analyse were shown in Table 3. Overall, the MHR was positively correlated with age, gender of male, smoking, a history of diabetes mellitus or chronic kidney disease, proBNP, creatinine, Creactive protein, white blood cell, NLR, PLR, NYHA class. The MHR also was negatively correlated with the albumin, cholesterol, hemoglobin, LVEF, a usage of sacubitril/valsartan or statins.

A multivariate Cox regression analysis with a stepwise retrospective model was applied to establish independent predictors of mortality at 1-year follow-up in patients with HFrEF, using variables that showed significant association with mortality in univariate analyzes. These variables are shown in Table 4. NLR, PLR, and MHR were found to be significant predictors of mortality as a result of multivariate analysis.

Table IV: Univariate analysis and independent predictors of mortality in multiple logistic regression analysis.

\begin{tabular}{|l|c|c|c|c|}
\hline & Unadjusted OR & P & Adjusted OR & P \\
\hline Age & $1.168(1.038-1.236)$ & 0.335 & $1.049(1.011-1.116)$ & 0.092 \\
\hline Male & $0.854(0.259-2.699)$ & 0.632 & & \\
\hline DM & $1.591(1.347-1.815)$ & 0.006 & $1.355(1.218-1.703)$ & 0.025 \\
\hline NYHA & $0.764(0.269-0.926)$ & 0.492 & $0.889(0.642-0.971)$ & 0.056 \\
\hline class & & & & \\
\hline LVEF & $0.574(0.446-0.942)$ & 0.012 & $0.761(0.359-0.932)$ & 0.008 \\
\hline PLR & $1.106(1.016-1.242)$ & 0.001 & $1.063(1.006-1.135)$ & 0.001 \\
\hline NLR & $1.041(1.019-1.090)$ & 0.003 & $1.027(1.003-1.062)$ & 0.001 \\
\hline MHR & $3.255(1.832-5.192)$ & 0.001 & $2.471(1.729-4.092)$ & 0.005 \\
\hline
\end{tabular}

OR: Odds ratio; DM: Diabetes mellitus; NHYA: New York Heart Association; NLR: Neutrophil to lymphocyte ratio; PLR: platelet to lymphocyte ratio; MHR: Monocyte to high-density lipoprotein cholesterol ratio; LVEF: Left ventricular ejection fraction;

The ROC curves of MHR, NLR and PLR for predicting mortality in HFrEF at 1 year followup are shown in Figure 2. We found that the AUC of MHR (0.831, \%95 CI: 0.799-0.869, $\mathrm{p}=0.001$ ) was significantly higher than both AUCs of NLR (0.649. \%95 CI: 0.573-0.721, $\mathrm{p}=0.001)$ and PLR (0.702. \%95 CI: 0.661-0.758, 
$\mathrm{p}=0.001$ ) The cut-off value of 6,39 can be used to predict the mortality with $83 \%$ sensitivity and $91 \%$ specificity.

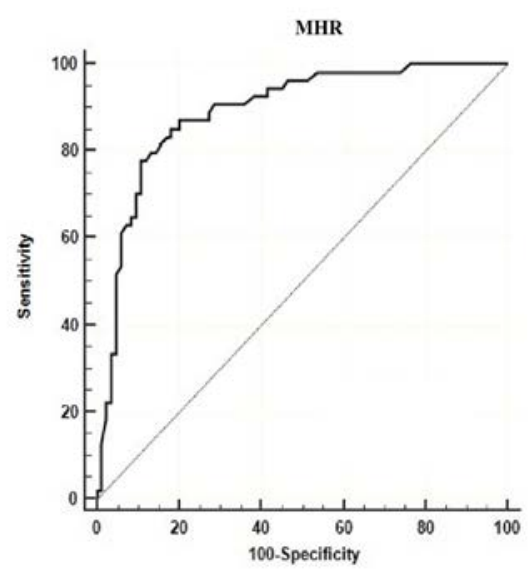

Figure 2. Roc Curve Analysis of MHR, NLR and PLR for predicting the mortality at 12 month follow-up

\section{DISCUSSION}

Our study is the first that demonstrate the relationship between MHR and mortality in patients with HFrEF. We also demonstrated the association between MHR and mortality. MHR might be accepted as an independent predictor of mortality in patients with HFrEF. In the complex management of patients with HFrEF, MHR can be used to predict mortality.

Inflammation is an extremely important factor in both the onset and progression of atherosclerotic cardiovascular disease ${ }^{2,3}$. However, the levels of different blood lipid components have critical importance in the atherosclerotic process. Inflammation has also been shown to be common in HF and different studies have indicated that it may be associated with adverse cardiovascular events ${ }^{12}$. Many inflammatory cytokines, as well as some proteolytic enzymes, which are increased as a result of the inflammatory stimulus, cause myocardial remodeling with a destructive effect on the myocardium and result in a reduction in left ventricular functions ${ }^{2,13}$.

$\mathrm{HF}$ is a disease with the high mortality rate despite all treatment methods. The estimated motility rate for one year is over $20 \% 14$. However mortality in HF studies are few in Turkey, and the mortality rate in Yllmaz and colleagues study was higher than the rate we found in our study ${ }^{13}$. If we want to explain this difference, firstly, it is acceptable for our study that the higher number of patients under sacubiril/valsartan treatment, which has a significant effect on mortality. Another important reason is the high rate of implanted defibrillator devices in the study patients. Many clinical scores and biomarkers have been identified for adverse outcome in patient with cardiovascular disease. The most important of these are advanced age, lower LVEF, proBNP level, etc. ${ }^{15,16}$. Several laboratory parameters correlated with inflammation were examined and represented to be the predictors of inhospital or long-term mortality in $\mathrm{HFrEF}^{17,18}$.

Recently, MHR has become a useful marker of poor prognosis in a varius cardiovascular diseases ${ }^{19-21}$. Higher levels of monocytes secreting proinflammatory and prooxidant cytokines and lower HDL-C, which has an antiinflammatory and antioxidant effect, after all MHR indicates inflammation and oxidation in the body ${ }^{22,23}$. HDL-C, which prevents the migration of macrophages into the vascular wall, neutralizes prooxidant and proinflammatory cytokines released from monocytes. In addition, it suppresses the activation, proliferation and differentiation of monocytes. Increasing monocytes converting to macrophage in the vascular wall and lower HDL-C levels contribute progressively to the atherosclerotic process ${ }^{24,25}$. Ganjali et al stated as a result of their study that MHR can be a parameter that shows the development and progression of atherosclerosis ${ }^{26}$. Bolayir et al, one of the studies on the correlation of MHR 
with adverse cardiovascular events, found that higher MHR predicts short-tem mortality in patients with stroke ${ }^{27}$. Wu et al. stated that it predicted major adverse cardiovascular outcomes and mortality in patients with ischemic heart disease treated by percutaneous coronary intervention (PCI) ${ }^{28}$. Similarly, Karataş et al. showed in their study that MHR correlated with major in-hospital cardiac events after primary PCI. In another study it was shown that MHR may be a strong predictor of future cardiovascular events in acute coronary syndrome patients ${ }^{29,30}$. However, there has been no available data about the MHR and mortality in HF patients until now. In this study, we showed that the MHR levels of non-survivor group were significantly elevated than the survivors group. In our study, we showed that MHR as a strong parameter can predict of mortality in HFrEF patients. In addition, the AUC of MHR was the highest AUC among all inflammatory parameters NLR, PLR for predicting mortality. It is thought that the the cut-off value of 6,39 for MHR can be used to predict the mortality in HFrEF.

\section{Study limitations}

This study contains few limited situations. Initially the design small. Second, we used a single MHR value instead of a timed trend for our analysis. Another, other common used inflammatory markers such as sedimentation were not analyzed and compared with the MHR.

\section{CONCLUSIONS}

The findings of our study showed a significant association between higher MHR and the risk of mortality in HFrEF patients. MHR was found to be superior to NLR and PLR for mortality at 1-year follow-up. Based on the current findings, it can be considered that MHR might be used as an inexpensive and practical parameter to predict mortality in HFrEF patients in Daily practice.
Ethics Committee Approval: The study was confirmed by the Ordu University Clinical Research Ethics Committee (12/03/2020-0645). Inscriptive aware consent was acquired obtained from all patients.

Declaration of Conflicting Interests: The authors declare that they have no conflict of interest.

Financial Disclosure: No financial support was received.

\section{REFERENCES}

1. Yancy CW, Jessup M, Bozkurt B, et al. 2013 ACCF/AHA guideline for the management of heart failure: a report of the American College of Cardiology Foundation/American Heart Association Task Force on Practice Guidelines. J. Am. Coll. Cardiol. 2013; 62: e147-e239.

2. Durmus E, Kivrak T, Gerin F, et al. Neutrophil-tolymphocyte ratio and platelet-to-lymphocyte ratio are predictors of heart failure. Arq. Bras. Cardiol. 2015; 105: 606-13.

3. Shirazi LF, Bissett J, Romeo F, et al. Role of inflammation in heart failure. Curr. Atheroscler. Rep. 2017; $19: 27$.

4. Sarhene M, Wang Y, Wei J, et al. Biomarkers in heart failure: the past, current and future. Heart Fail Rev. 2019; 24: 867-903.

5. Mocan M, Mocan Hognogi LD, Anton FP, et al. Biomarkers of inflammation in left ventricular diastolic dysfunction. Dis Markers. 2019; 2019: 7583690 .

6. Karatas A, Turkmen E, Erdem E, et al. Monocyte to high-density lipoprotein cholesterol ratio in patients with diabetes mellitus and diabetic nephropathy. Biomark Med. 2018; 12: 953-9.

7. Açıkgöz SK, Açıkgöz E, Şensoy B, et al. Monocyte to high-density lipoprotein cholesterol ratio is predictive of in-hospital and five-year mortality in STsegment elevation myocardial infarction. Cardiol J. 2016; 23: 505-12.

8. Trajkovska KT, Topuzovska SJAjoc. High-density lipoprotein metabolism and reverse cholesterol transport: strategies for raising HDL cholesterol. Anatol. J. Cardiol. 2017; 18: 149.

9. Wei XB, Chen F, Huang JL, et al. Novel Risk Biomarker for Infective Endocarditis Patients With 
Normal Left Ventricular Ejection Fraction-Monocyte to High-Density Lipoprotein Cholesterol Ratio-. Circ. J. 2017; 82: 283-88.

10. Kızltunç E, Alsancak Y, Sezenöz B, et al. Relationship between monocyte/high-density lipoprotein cholesterol ratio and angiographic severity and extent of coronary artery disease. Kosuyolu Heart Journal 2017; 20: 30-5.

11. Ünal S, Yayla Ç, Gayretli Yayla K, et al. Kalsifik Aort Darlığının Yeni Bir Enflamatuvar İndikatörü: Monosit/Yüksek Yoğunluklu Lipoprotein Kolesterol Oranı MN Kardiyoloji 2018; 25: 108-14.

12. Gungoren F, Senturk T, Ozturk A, et al. Serum paraoxonase activity in patients with ischaemic and nonischaemic dilated cardiomyopathy. Acta Cardiol. 2018; 73: 85-90.

13. Yılmaz MB, Aksakal E, Aksu U, et al. Snapshot evaluation of acute and chronic heart failure in reallife in Turkey: A follow-up data for mortality. Anatol J Cardiol. 2020; 23: 160.

14. Straw S, Byrom R, Gierula J, et al. Predicting oneyear mortality in heart failure using the 'Surprise Question': a prospective pilot study. Eur J Heart Fail. 2019; 21: 227-34.

15. Miró Ò, Rossello X, Gil V, et al. Predicting 30-Day Mortality for Patients With Acute Heart Failure in the Emergency Department: A Cohort Study. Ann Intern Med. 2017; 167: 698-705.

16. Simsek MA, Degertekin M, Turer Cabbar A, et al. NT-proBNP levels and mortality in a general population-based cohort from Turkey: a long-term follow-up study. Biomark Med. 2018; 12: 1073-81.

17. Karauzum K, Karauzum I, Ural D, et al. A simple discharge risk model for predicting 1-year mortality in hospitalised acute decompansated heart failure patients with reduced ejection fraction. Acta Cardiol. 2018; 73: 164-70.

18. Doğan A. Pulmonary Artery Pulsatility Index As A Predictor Of Cardiac Mortality In Advanced Chronic Heart Failure: Is It Beyond Right Atrial Pressure? Dicle Medical Journal 2020; 47: 304-11.

19. Çiçek G, Kundi H, Bozbay M, et al. The relationship between admission monocyte HDL-C ratio with shortterm and long-term mortality among STEMI patients treated with successful primary PCI. Coron Artery Dis. 2016; 27: 176-84.
20. Alagöz A, Acar B , Güngen B , et al. A New Marker in Acute Ischemic Stroke Patients: Monocyte/HDL Ratio. Konuralp Medical Journal 2020; 12.

21. Sari A, Ulu MS, Kazan S, et al. Comparison of Monocyte/HDL Ratio In Routine Hemodialysis And Peritoneal Dialysis Patients. 2020; 47: 137-9.

22. Onalan E. The relationship between monocyte to high-density lipoprotein cholesterol ratio and diabetic nephropathy. Pak J Med Sci. 2019; 35: 1081.

23. Uslu AU, Sekin Y, Tarhan G, et al. Evaluation of Monocyte to High-Density Lipoprotein Cholesterol Ratio in the Presence and Severity of Metabolic Syndrome. Clin Appl Thromb Hemost. 2018; 24: 82833.

24. Ertek S. High-density lipoprotein (HDL) dysfunction and the future of HDL. Curr Vasc Pharmacol. 2018; 16: 490-8.

25. Karabacak M, Varol E, Kahraman F, et al.Low highdensity lipoprotein cholesterol is characterized by elevated oxidative stress. Angiology. 2014; 65: 92731.

26. Ganjali S, Gotto AM Jr, Ruscica M, et al. Monocyteto-HDL-cholesterol ratio as a prognostic marker in cardiovascular diseases. J Cell Physiol. 2018; 233: 9237-46.

27. Bolayir A, Gokce SF, Cigdem B, et al. Monocyte/high-density lipoprotein ratio predicts the mortality in ischemic stroke patients. Neurol Neurochir Pol. 2018; 52: 150-5.

28. Wu TT, Zheng YY, Chen Y, et al. Monocyte to highdensity lipoprotein cholesterol ratio as long-term prognostic marker in patients with coronary artery disease undergoing percutaneous coronary intervention. Lipids Health Dis. 2019; 18: 180.

29. Karataş MB, Çanga Y, Özcan KS, et al. Monocyte to high-density lipoprotein ratio as a new prognostic marker in patients with STEMI undergoing primary percutaneous coronary intervention. Am J Emerg Med. 2016; 34: 240-4.

30. Cetin MS, Ozcan Cetin EH, et al. Monocyte to HDL Cholesterol Ratio Predicts Coronary Artery Disease Severity and Future Major Cardiovascular Adverse Events in Acute Coronary Syndrome. Heart Lung Circ. 2016; 25: 1077-86. 